\title{
Treatment Motivation in Lung Tuberculosis Patients at Public Health Centres in Denpasar City during COVID-19 Pandemic
}

\author{
Jonathan Setiawan', Ida Ayu Alit Widhiartini'2, I Gusti Made Aman³ \\ ${ }^{1}$ Faculty of Medicine, Udayana University, Denpasar, Indonesia \\ ${ }^{2,3}$ Department of Pharmacology, Faculty of Medicine, Udayana University, Denpasar, Indonesia \\ Corresponding Author: Ida Ayu Alit Widhiartini (widhiartini@unud.ac.id)
}

DOI: https://doi.org/10.52403/ijrr.20220107

\begin{abstract}
Treatment motivation among patients were heavily influenced by duration of therapy and existing side effects. TB supervisors motivated patients in their therapy. Limited communication from TB supervisors due to COVID-19 pandemic risked lowering treatment motivation in TB patients. Objective: get a general description of treatment motivation in TB patients from PHC in Denpasar. Method: descriptive observational with cross-sectional design in March - August 2021 at five PHC in Denpasar area. This study was done online using questionnaire with Google Forms application. Motivation is grouped into low, moderate, and high based on scores from internal factors, external factors, confidence in treatment, and interpersonal help seeking. Results: $86 \%$ of patients (43 people) had high treatment motivation, $12 \%$ of patients (6 people) have moderate treatment motivation, and two percent of patients (1 people) had low treatment motivation. Summary: Most of TB patients had high treatment motivation (86\%). Communication between TB supervisors and patients are highly advised to motivate patients and increase success rate of therapy.
\end{abstract}

Keywords: [Anti tuberculosis drugs, Lung tuberculosis, Treatment motivation]

\section{INTRODUCTION}

Tuberculosis (TB) is one of the oldest diseases known globally, and still has a high incident and mortality rate: 10 million new cases were reported and 1,2 million deaths worldwide in 2019. Indonesia is one the countries with highest TB burden in the world, with an incident rate 845,000 and death rate of 96,000 in 2020. ${ }^{[1]}$ World Health Organization is collaborating with governments in various countries to eradicate TB by 2030. One of the solutions is to implement Directly Observed Treatment Short-Course (DOTS) system as a therapy for TB disease. DOTS takes minimally 6 months by consuming antituberculosis drugs accompanied by a supervisor.

Patients are declared dropout/failed the therapy if they forgot to consume the drugs for one day. Patients who fail the therapy are highly encourage to repeat the therapy from the start with longer duration and with additional drugs. ${ }^{[2]}$ Not adhering to taking the medicine is stated as the main cause of therapy failure and drug resistance TB. This trait is caused by unwanted and disturbing side effects and long duration of therapy. [3] These factors are strongly influenced by treatment motivation of each patient undergoing the therapy. [4] Supervisors play an important role in maintaining patient motivation during the therapy. Supervisor accompanies, and ensure that the patient takes the drug regularly, giving important information regarding TB, and provides emotional support so that the patient will not be bored or discontinue the therapy. ${ }^{[5]}$ 
COVID-19 pandemic has hampered the communication between supervisors and the patient, thus $75 \%$ of supervisors carry out their duties online. Several difficulties occurred by doing so, such as: network problems and or inability of patients operating a smartphone. Face-to-face therapy is proven to be more effective than doing it virtually. [6] With these dire conditions, COVID-19 pandemic creates uncertainty in treatment motivation in patients and thus might lower the treatment success rate and ultimately hinders the goal of TB eradication by 2030. This study was designed to determine the treatment motivation in lung TB patients at Public Health Centers (PHC) in Denpasar during COVID-19 pandemic.

\section{MATERIALS \& METHOD}

The design of this study is descriptive observational with a crosssectional approach. This study was carried out for 6 months (March-August 2021). The study was conducted in Bali province in PHC at Denpasar city, with data of the patients of lung TB obtained from Indonesia Association for Tuberculosis Eradication at each PHC. The sample used in this study were lung $\mathrm{TB}$ patients who were still undergoing therapy in five different PHC at Denpasar municipal area during COVID-19 pandemic. Samples were taken with purposive sampling technique at five PHC in Denpasar area and obtained 50 samples that fulfil the inclusion criteria. The research variables consisted of a dependent variable: treatment motivation, and the independent variables: age, gender, educational background, occupation, and income.

Treatment motivation was measured using Treatment Motivation Questionnaire (TMQ) which was modified from Ryan and Plant's 1995 study regarding alcohol addiction therapy and was distributed among samples via Google Forms. ${ }^{[7]} \mathrm{TMQ}$ consists of 26 statements that measure 4 aspects to establish an individual's motivation to recover: internal motivation, external motivation, factor in believing treatment, and factor in seeking help. The patient's response is based on a five-point Likert Scale where point 1 means "Strongly disagree" to point 5 "Strongly agree". TMQ was declared valid and reliable by Yapisi's research in 2006 with a reliability coefficient of 0.854. ${ }^{[8]}$ Data was processed with Microsoft Excel 2013, and analysed descriptively by univariate and bivariate to determine the distribution of the frequency and proportion of the characteristics of each variable studied. This study has been approved by the Ethics Commission of Faculty of Medicine Udayana University and obtained permission from Denpasar City Health Office.

\section{RESULT}

Figure 1 shows the proportion of treatment motivation among patients which were dominated by high motivation (86\%) followed by moderate motivation (12\%) and low motivation (2\%).

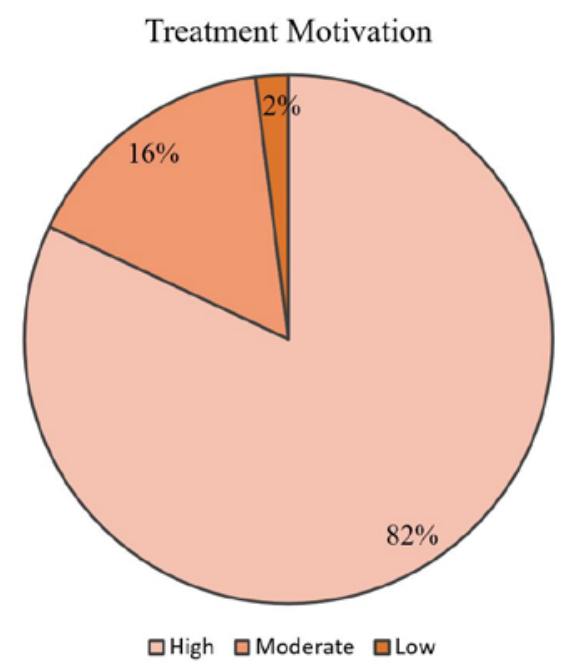

Figure 1. Proportion of Treatment Motivation

Characteristics of samples are shown in Table 1 which consists of 50 patients. Gender in this study was dominated by male (64\%). Range of age for most patients were 21-30 years old and 31-40 years old (both 26\%). Last educational background was mostly senior high school (42\%), followed by Bachelor/Diploma (24\%). Occupations varied greatly among patients, but were 
Jonathan Setiawan et.al. Treatment motivation in lung tuberculosis patients at public health centres in Denpasar City during COVID-19 pandemic.

dominated by group of temporary workers/people who have not worked for 6 months (42\%). In terms of income per month, most patients had less than IDR $2,200,000$ or even no income at all (70\%).

Table 2 shows the description of patients' characteristics against the level of treatment motivation they showed during TB therapy. Females had higher treatment motivation (94.4\%) compared to males (81.3\%). In terms of age range, young adults or 21-40 years old had higher treatment motivation (92.3\%) whereas elderly or $>60$ years old had one patient that showed low motivation (2\%). Educational background showed middle school and post graduate had the highest treatment motivation (100\%) compared to the rest. There were many occupations that showed high treatment motivation. In terms of income per month, highest treatment motivation was at group $\geq$ IDR 2,200,000.

Table 1. Characteristics of Research Subjects

\begin{tabular}{|c|c|c|}
\hline No. & Variable & $\begin{array}{l}\text { Frequency } \\
\text { n (\%) }\end{array}$ \\
\hline \multirow[t]{3}{*}{1} & Gender & \\
\hline & Male & $32(64)$ \\
\hline & Female & $18(36)$ \\
\hline \multirow[t]{6}{*}{2} & Age (years) & \\
\hline & $21-30$ & $13(26)$ \\
\hline & $31-40$ & $13(26)$ \\
\hline & $41-50$ & $9(18)$ \\
\hline & $51-60$ & $9(18)$ \\
\hline & $>60$ & $6(12)$ \\
\hline \multirow[t]{7}{*}{3} & Educational Background & \\
\hline & None & $3(6)$ \\
\hline & Elementary School & $8(16)$ \\
\hline & Middle School & $5(10)$ \\
\hline & Senior High School & $21(42)$ \\
\hline & Bachelor or Diploma & $12(24)$ \\
\hline & Postgraduate & $1(2)$ \\
\hline \multirow[t]{9}{*}{4} & Occupation & \\
\hline & None or not working for 6 months & $21(42)$ \\
\hline & Untrained Labor & $6(12)$ \\
\hline & Small Farmer & $1(2)$ \\
\hline & Retirement & $4(8)$ \\
\hline & Skilled Labor & $7(14)$ \\
\hline & Small Business Owner & $7(14)$ \\
\hline & Teacher/Lecturer & $2(4)$ \\
\hline & Health Workers & $2(4)$ \\
\hline \multirow[t]{4}{*}{5} & Income per month & \\
\hline & None or $\leq$ IDR $2,200,000$ & $35(70)$ \\
\hline & $\geq$ IDR $2,200,000$ & $12(24)$ \\
\hline & $\geq$ IDR $4,500,000$ & $3(6)$ \\
\hline
\end{tabular}

Table 2. Treatment Motivation Description

\begin{tabular}{|l|l|l|l|l|}
\hline No. & Variable & $\begin{array}{l}\text { Low } \\
\mathbf{n}(\mathbf{\%})\end{array}$ & $\begin{array}{l}\text { Moderate } \\
\mathbf{n}(\mathbf{\%})\end{array}$ & $\begin{array}{l}\text { High } \\
\mathbf{n}(\mathbf{\%})\end{array}$ \\
\hline $\mathbf{1}$ & Gender & & & \\
\hline & Male & $1(3.1)$ & $5(15.6)$ & $26(81.3)$ \\
\hline & Female & $0(0)$ & $1(5.6)$ & $17(94.4)$ \\
\hline $\mathbf{2}$ & Age (years) & & & \\
\hline & $21-30$ & $0(0)$ & $1(7.7)$ & $12(92.3)$ \\
\hline & $31-40$ & $0(0)$ & $1(7.7)$ & $12(92.3)$ \\
\hline & $41-50$ & $0(0)$ & $1(11.1)$ & $8(88.9)$ \\
\hline & $51-60$ & $0(0)$ & $1(11.1)$ & $8(88.9)$ \\
\hline & $>60$ & $1(16.7)$ & $1(16.7)$ & $4(66.7)$ \\
\hline $\mathbf{3}$ & Educational Background & & & \\
\hline & None & $1(33.3)$ & $0(0)$ & $2(66.7)$ \\
\hline & Elementary School & $0(0)$ & $1(12.5)$ & $7(87.5)$ \\
\hline & Middle School & $0(0)$ & $0(0)$ & $5(100)$ \\
\hline & Senior High School & $0(0)$ & $3(14.3)$ & $18(85.7)$ \\
\hline & Bachelor or Diploma & $0(0)$ & $2(16.7)$ & $10(83.3)$ \\
\hline & Postgraduate & $0(0)$ & $0(0)$ & $1(100)$ \\
\hline $\mathbf{4}$ & Occupation & & & \\
\hline & None or not working for 6 months & $1(4.8)$ & $2(9.5)$ & $18(85.7)$ \\
\hline & Untrained Labor & $0(0)$ & $0(0)$ & $6(100)$ \\
\hline & Small Farmer & $0(0)$ & $1(100)$ & $0(0)$ \\
\hline & Retirement & $0(0)$ & $1(25)$ & $3(75)$ \\
\hline & Skilled Labor & $0(0)$ & $0(0)$ & $7(100)$ \\
\hline & Small Business Owner & $0(0)$ & $3(42.9)$ & $4(57.1)$ \\
\hline & Teacher/Lecturer & $0(0)$ & $0(0)$ & $2(100)$ \\
\hline & Health Workers & $0(0)$ & $0(0)$ & $2(100)$ \\
\hline $\mathbf{5}$ & Income per month & & & \\
\hline & None or $\leq$ IDR 2,200,000 & $1(2.9)$ & $4(11.4)$ & $30(85.7)$ \\
\hline & $\geq$ IDR 2,200,000 & $0(0)$ & $1(8.3)$ & $11(91.7)$ \\
\hline & $\geq$ IDR 4,500,000 & $0(0)$ & $1(33.3)$ & $2(66.7)$ \\
\hline
\end{tabular}

\section{DISCUSSION}

The majority of patients in this study were male (64\%). In various references, it is stated that men are more susceptible to lung
TB than women. [1] This is supported by Genet et al findings in $2018{ }^{\text {[9] }}$, which stated that smoking and consuming alcohol were found to be higher in men than women. Risk 
factors of TB include smoking [1], alcohol consumption and other comorbidities such as HIV and diabetes. These conditions described the males' behavior and tendencies, thus making it more susceptibility to lung TB compared to women. The females had higher treatment motivation (94.4\%) compare to male (81.3\%). However, these findings were not in sync with Taylor et al study in 2017 [10] regarding motivation to recover in patients undergoing therapy. Taylor's result stated that there was no significant difference between gender groups. In addition, according to Giordan's theory in $2016^{\text {[11] }}$ there were two motivational factors: internal and external. Hence, gender does not play a role in determining the motivation of a person.

Patients within the age range 21-40 years had shown higher treatment motivation compared to the elderly. However, according to Dinda Kinasih and Wayuningsih study in $2012^{\text {[12] }}$, they stated that elderly had high motivation when undergoing therapy. Hence, age does not have a significant association with treatment motivation, but a clear goal will trigger the internal factor of a person to achieve it. [11] In general, people within the age 21-40 years old were considered 'young adults' [13], where their dreams and plans were come to a realization. This behavior gave young adults a tendency to have a very strong motivation in this phase of life. ${ }^{[14]}$

Examined from the educational background, middle school and postgraduates all had high level of treatment motivation (100\%). However, this finding is inconsistent with study from Maftuhah et al in $2018^{\text {[15] }}$ which stated that there was a significant relationship between one's knowledge and treatment motivation. Higher knowledge leaded to higher motivation. Higher knowledge also meant one's capability to understand and apply new information to use. [16] From these results, postgraduates should have the highest treatment motivation, not equal with the middle school educational background.
COVID-19 pandemic had significant effect on people's occupation and income. [17] Most of the patients in this study (70\%) had lost their work and thus had no or lower income per month. Although there were lots of occupational group in this study who had high treatment motivation, unfortunately they were no studies supporting the association between them. Similarly goes for income per month, where there were no supporting studies or evidence that may prove that higher income leads to higher treatment motivation.

Patient with low treatment motivation (2\%) was in the following characteristics: male sex group, elderly (age $>60$ years), no educational background, jobless, and had no income. If we looked at the statements number 1 until 11 on the TMQ, it evaluated internal motivation of an individual. In this particular respondent with low treatment motivation, 9 out of 11 statements (81.8\%) were given 1 point which meant "Strongly disagree" whereas other elderly patients in this study who on average gave 5 points, "Strongly agree". Difference in age and educational background may be the reason the patient had low internal treatment motivation. He was 77 years old and was the oldest among all patients in this study. In addition, he had no educational background to understand the complexity of diseases and health protocols in this current era. These factors made the patient lost his enthusiasm in his life to achieve a certain goal, specifically to get better.

Overall, COVID-19 pandemic had negative impact on mostly everything, including controlling the spread and treatment for TB disease in a country. Several countries allocated their funds, human resources, health workers and staff from PHC or hospitals to tackle the uproaring pandemic. Although on one side it was beneficial for a much pressing matter, it slowed the goal to eradicate TB in 2030 as it may become a temporary neglected disease. TB supervisors, one of the important factors to maintain one's treatment motivation, had 
Jonathan Setiawan et.al. Treatment motivation in lung tuberculosis patients at public health centres in Denpasar City during COVID-19 pandemic.

fewer workers and work hours due to policies regarding COVID-19. An alternative way to this problem was to recruit or train a family member to become the TB supervisor for each respective patients. There were no exceptions or limitations for those who had the position as a TB supervisor, as long as the patient had the consent, agreed, and fit to work together.

In this pandemic, training or recruiting could be done online or giving a handbook containing TB supervisor duties and role whilst accompanying the patient in therapy. In light to this, it is hopeful that this solution could be a help to maintain high treatment motivation in patients undergoing TB therapy and thus increasing the cure rate for TB around the world.

\section{CONCLUSION}

Treatment motivation in lung TB patients at PHC in Denpasar city is as follows: $86 \%$ of patients (43 people) had high treatment motivation. $12 \%$ of patients (6 people) had moderate treatment motivation, and $2 \%$ of patients (1 people) had low treatment motivation. Although there was only one who had low treatment motivation, this finding deserved to be noted as motivation itself affect the recovery rate of lung TB patients. ${ }^{[18]}$ Further research could be carried out to compare treatment motivation of lung TB patients during and after the pandemic. This study is useful to see the development of success rate for therapy in lung TB patients before and after the pandemic. The results can then be used to create a strategy to maintain the success rate of lung TB therapy, thus achieving End TB Strategy in 2030.

\section{Informed Consent and Patient Details:}

The authors declare that this case report does not contain any personal information that could lead to identification of patient(s) and/or volunteers.

\section{Acknowledgment:}

We would like to thank every author that have been involved in this study from the beginning until the publication process.

\section{Conflict of Interest: None}

\section{Source of Funding: None}

\section{Ethical Approval:}

This study has obtained ethical clearance issued by the Research Ethic Commission of Faculty of Medicine, Udayana University, Sanglah General Hospital, Denpasar. Ethical Clearance Number: 163/UN14.2.2.VII.14/LT/2021.

\section{REFERENCES}

1. World Health Organization. Global Tuberculosis Report 2020. Geneva;

2. World Health Organization. What is DOTS ? Geneva;

3. Nugrahaeni DK, Malik US. Analisis Penyebab Resistensi Obat Anti Tuberkulosis. J Kesehat Masy. 2013;8(2): 113-20.

4. Grahame Moore M. Handbook of Distance Education. 4th ed. Grahame Moore M, C. Diehl W, editors. New York: Routledge; 2019. 648 p.

5. Riyanti E, Yardes N. Peran Pendamping Minum Obat ( PMO ) dalam Keteraturan Konsumsi Obat Klien TBC. J Keperawatan. 2019;4(1):54-61.

6. Chaudhary T, Kanodia A, Verma H, Amit C. A Pilot Study Comparing Teletherapy with the Conventional Face-to-Face Therapy for Speech-Language Disorders. Indian J Otolaryngol Head Neck Surg [Internet]. 2021;73(3):366-70. Available from: https://doi.org/10.1007/s12070-02102647-0

7. Ryan RM, Plant RW. Initial motivations for alcohol treatment: relations with patient characteristics, treatment involvement, and dropout richard m. ryan. Addict Behav. 1995;20(3):279-97.

8. Yapisi F, Ve G, Rl G, Evren C, Saatçio Ö, Dalbudak E, et al. Factorial Structure and Reliability and Validity of Turkish Version Treatment Motivation Questionnaire (TMQ) in Alcohol Dependents. 2006; 90(216):11722. 
9. Genet A Amere, Pratibha Nayak, Argita D Salindri, K M V Narayan MJM. Running head: TB Disease and Death Attributable to Smoking IT SC IT. Am J Epidemiol. 2018;187(9):1846-55.

10. Taylor LR, Caudy M, Blasko BL, Taxman FS, Taylor LR, Caudy M, et al. Differences by Gender in Predictors of Motivation Among Substance Abuse Treatment Participants Differences by Gender in Predictors of Motivation Among Substance Abuse. Subst Use Misuse [Internet]. 2017;52(4):468-76. Available from: http://dx.doi.org/10.1080/10826084.2016.12 45332

11. Giordan A. Motivare i pazienti con patologie croniche. 2016;(March):57-63.

12. Dinda Kinasih K, Wahyuningsih A. Peran Pendampingan Spiritual Terhadap Motivasi Kesembuhan Pada Pasien Lanjut Usia. STIKES. 2012;5(1):1-10.

13. Dyussenbayev A. Age Periods Of Human Life. 2017;4(6):258-63.

14. Sterns HL, Miklos SM. The Aging Worker in a Changing Environment : Organizational and Individual Issues. $\mathrm{J}$ Vocat Behav. 1995;47:248-68.

15. Maftuhah A, Setyaningsih I, Susilo R. Relationship Of Patient Knowledge On Potential Motivation In Training Metadon
Health Therapy In PTRM Gunung Jati Kota Cirebon. 2018;2(2):50-7.

16. Ivoryanto E, Sidharta B, Illahi RK. Hubungan Tingkat Pendidikan Formal Masyarakat terhadap Pengetahuan dalam Penggunaan Antibiotika Oral di Apotek Kecamatan Klojen Relationship Between Formal Education Level and Knowledge About Oral Antibiotics Used in Klojen Subdistrict Pharmacies. 2017;2(2):31-6.

17. Achiel Y, Soffy B, Eka AA, Kumaya JR. Dampak Pandemi COVID-19 Bagi Pekerja "PHK, Pemotongan Gaji, dan Motivasi Kerja.” 2020;1(2):1-10.

18. Sirait RA, Lubis IJV, Sudirman J, Lubuk N, Kab P, Serdang D, et al. Pengaruh Kepatuhan dan Motivasi Penderita TB Paru di Puskesmas Tanung Morawa Kabupaten Deli Serdang Tahun 2017. 2018;1(1):31-6.

How to cite this article: Jonathan Setiawan, Ida Ayu Alit Widhiartini, I Gusti Made Aman. Treatment motivation in lung tuberculosis patients at public health centres in Denpasar City during COVID-19 pandemic. International Journal of Research and Review. 2022; 9(1): 45-50. DOI: https://doi.org/10.52403/ijrr. 20220107 